Check for updates

The BMJ

Cite this as: $B M J 2020 ; 371: \mathrm{m} 4729$ http://dx.doi.org/10.1136/bmj.m4729 Published: 03 December 2020

\section{Covid-19: Bereaved families, unions, and charities demand immediate public inquiry to save lives}

\section{Zosia Kmietowicz}

Families who have lost relatives to covid-19 have come together with trade unions and campaigning organisations to demand that the UK prime minister order an immediate statutory public inquiry into the government's handling of the covid-19 pandemic to minimise further loss of life.

In a letter to Boris Johnson they argue that the pandemic inquiry must begin with a "rapid review phase," like that at the beginning of the Taylor inquiry after the Hillsborough disaster, so that initial findings can be reported quickly. ${ }^{1}$

Organised by Covid-19 Bereaved Families for Justice, the letter's signatories include the BMA, the Trades Union Congress, Unite, the GMB, Amnesty International, UK Black Pride, the Race Equality Foundation, and Disability Rights UK.

They say that the inquiry should examine the effectiveness of the UK's test and trace programme, how the government has made and communicated key decisions and risk levels, and the impact of covid-19 on ethnic minority communities. It should also look at how the NHS is responding to the crisis, focusing on the effectiveness of NHS 111, the threat of covid-19 transmission in care homes and hospitals, and the NHS's ability to carry out other urgent treatments.

Covid-19 Bereaved Families for Justice, which represents more than 1600 people who have lost a relative to covid-19, has been trying to meet with Johnson for months. It was promised a meeting in August, ${ }^{2}$ only for the prime minister to change his mind days later. ${ }^{3}$

\section{Time to learn lessons}

Jo Goodman, cofounder of Covid-19 Bereaved Families for Justice, said, "We have been making the case for an urgent inquiry and rapid review since June. If the prime minister [had] met with us as we asked and listened to what we had to say then, we may not be in the situation we are now.

"It is clear a covid-19 inquiry cannot be delayed any longer. It must be a statutory public inquiry, and it must have a rapid review first stage like the Taylor review after the Hillsborough disaster. No more people have to die. It's time to learn lessons and save lives."

Chaand Nagpaul, BMA chair of council, said, "It is tragic that over 59 ooo people in the UK have lost their lives to covid-19, putting us in the position of having more fatalities than any country in Europe. With a second wave still resulting in thousands of patients being hospitalised and dying each week, it is essential that there is a rapid review of lessons already learnt-and that action is taken to manage the pandemic and the pressure on the NHS, as well as to reduce further avoidable loss of lives.

"In the longer term, a full public inquiry must deliver a comprehensive assessment of how the government has managed covid-19, how effectively public money has been deployed, and what needs to change to ensure we can be best prepared for any future pandemic and properly safeguard the health of the nation."

1 Covid-19 Bereaved Families for Justice. Letter to the prime minister. 3 Dec 2020. https://drive.google.com/file/d/1sAWqLArz2MTtFdTrffvzBUnKuHTsToeN/view.

2 Rimmer A. Covid-19: Prime minister agrees to meet bereaved families. BMJ

3 lacobucci G. Covid-19: UK prime minister says he will only meet bereaved families when they drop threat of legal action. BMJ2020;370:m3424. doi: 10.1136/bmj.m3424 pmid: 32878884

This article is made freely available for use in accordance with BMJ's website terms and conditions for the duration of the covid-19 pandemic or until otherwise determined by BMJ. You may use, download and print the article for any lawful, non-commercial purpose (including text and data mining) provided that all copyright notices and trade marks are retained. 2020;370:m3356. doi: 10.1136/bmj.m3356 pmid: 32855149 